Journal of Engineering and Applied Sciences 14 (Special Issue 6): 9352-9357, 2019

ISSN: 1816-949X

(C) Medwell Journals, 2019

\title{
Radionuclides Concentrations in Soils of Al-Hawija Technical Institute-Kirkuk Governate, Iraq
}

\author{
${ }^{1}$ S.F. Mohammed, ${ }^{2}$ Samera H. Abdullah and ${ }^{3}$ Esam S. Ali \\ ${ }^{1}$ Department of Electrical Techniques, \\ ${ }^{2}$ Department of Nursing, Technical Institute Kirkuk, Northern Technical University, Mosul, Iraq \\ ${ }^{3}$ Department of Physics, College of Education/Tuzkhurmatu, University of Tikrit, Tikrit, Iraq \\ sameen1966@yahoo.com
}

\begin{abstract}
The aim of this study is to evaluate the level of natural and industrial radiation activity for soil samples of Al-Hawija Technical Institute which by using the High Purity Germanium detector (HPGe). It has been taken nine soil samples from Al-Hawija Technical Institute which located in Al-Hawija District-Kirkuk governate. The result showed that the specific activity concentration values (Bq. $\mathrm{kg}^{-1}$ unite) for radium ${ }^{226} \mathrm{Ra}$, lead ${ }^{214} \mathrm{~Pb}$, lead ${ }^{212} \mathrm{~Pb}$, Actinium ${ }^{228} \mathrm{Ac}$, Cesium ${ }^{137} \mathrm{Cs}$ and potassium ${ }^{40} \mathrm{~K}$ and the calculation of the risk rates for radium equivalent $67.487 \mathrm{~Bq} \cdot \mathrm{kg}^{-1}$, effect concentration factor 0.496 , internal risk factor 0.256 , external risk factor 0.182 , absorbing values dose in air $32.215 \mathrm{nGy} . \mathrm{kg}^{-1}$, internal annual effective dose values $0.158 \mathrm{mSv} . \mathrm{y}^{-1}$ annual effective external dose $0.040 \mathrm{mSv} \cdot \mathrm{y}^{-1}$, increased risk of cancer $0.139 \times 10^{-3}$, annual effective external dose $0.301 \mathrm{mSv} . \mathrm{y}^{-1}$ in all soil samples are lower than the average international value, so, the soils in these locals have no negative effect in human health or the environment.
\end{abstract}

Key words: Radium, radiation concentrations, High-Purity Germanium (HPGe) detector, Al-Hawija Technical Institute-Kirkuk Governorate, human health (Bq. $\mathrm{kg}^{-1}$ unite)

\section{INTRODUCTION}

Radiation is an effective part of our environment in which we live, since, all people will expose to it through soil, water, air and food. The radiation sources divided to two important sources, natural (cosmic radiation) and artificial radiation source that is man-made. Radiation is a natural part of the environment in which we live and everyone will expose to radiation through soil, water, air and food (Green et al., 1992). The radiation sources which can be divided into two important sources. The first form is the natural radiation source were found in the free nature such as the cosmic radiation coming from the stars, sun, galaxies and radiation that have existed, since, the origin of the universe. This type known radiological background radiation that includes radiation in rocks, water, soil and our bodies. The second type is the artificial radiation source which is man-made. This includes X-rays which generated by the $\mathrm{X}$-ray tube or in the medical and industrial accelerators, gamma, alpha and beta rays which are all generated by nuclear reactions, neutron or photon activation and activation by charged particles, nuclear accidents, nuclear reactors, etc. (UNSCEAR., 1988). Soil pollution is generally, happened when adding or losing some or all its components which cause an imbalance, change its natural, for either the chemical or biological properties and affects directly or indirectly in those live in its surface such us humans, plants or animals. The scientific and technological progress in the manufacture of radioactive materials and their application in many field became the most risk threats the elements of environment including the soil, so, it became necessary to know the nature and dangers of these materials and how to be protect from them and circulate them safely (Selvaskarapadian et al., 2000). The main concept of soil pollution mainly depends on the information about transitions and accumulation away from the site of contamination. The accumulation and movement of radioactive materials depends on the interaction of materials and compounds with the solid part of the soil. This interaction reflects the soil's ability to retain and reactivate radioactive material. The physical, chemical and biological properties of the solid components can be determine their ability to retain radioactive materials. On the other hand, rainfall, irrigation

Corresponding Author: S.F. Mohammed, Department of Electrical Techniques, Technical Institute Kirkuk, Northern Technical University, Mosul, Iraq, sameen1966@yahoo.com 
water quantity, cultivated plant species and soil management processes largely determine the type and amount of radioactive contaminants into groundwater or their transmission to plants or other media such as air and water. In the soil, the radiation content is on the surface within $1-2 \mathrm{~cm}$ and $90 \%$ of the radioactive material is removed by wind and rain in the first few months of soil contamination as well as the natural degradation of radioactive material (UNEP., 2000). The aim of this study is to evaluate level of natural and industrial radiation activity for soil samples from Al-Hawija Technical Institute using the spectroscopy technique that has a high purity germanium detector. All of these process has been done, to be take the samples from the site after finishing all the military operations. As a result, this study has contributed in accounted the level of radiation in the soil taken samples from a polluted location, Al-Hawija Technical Institute. Eventually, it recorded values lower than danger numbers which allowed values as compared to the international limits.

\section{MATERIALS AND METHODS}

The theoretical side: Specific Activity concentration (A) is defined as the radiation effectiveness of the unit of mass the radioactive material. Specific activity concentration is calculated by using Eq. 1:

$$
\mathrm{A}(\mathrm{Bq} / \mathrm{kg})=\frac{\mathrm{N}}{\varepsilon\left(\mathrm{E}_{\gamma}\right) \cdot \mathrm{I}_{\gamma}\left(\mathrm{E}_{\gamma}\right) \cdot \mathrm{M} \cdot \mathrm{t}}
$$

Where:

$$
\begin{aligned}
& \mathrm{N}=\text { The Net count under the top } \\
& \cdot(\mathrm{E} \bullet) \text { The Efficiency of the gamma ray detector } \\
& \mathrm{M}=\text { The Mass of the model in } \mathrm{kg} \text { and } \mathrm{t} \text { is the } \\
& \text { counting time in the second unit } \\
& \mathrm{I} \cdot(\mathrm{E} \bullet)=\text { The percentage of the potential Emission of } \\
& \text { gamma from the radionuclides under study }
\end{aligned}
$$

Radium equivalent activity $\left(\mathrm{Ra}_{\mathrm{eq}}\right)$ is defined as a radiation factor used to ensure the uniform distribution of natural radionuclides represented by ${ }^{226} \mathrm{Ra},{ }^{232} \mathrm{Th}$ and ${ }^{40} \mathrm{~K}$. It is measured in Bq. $\mathrm{kg}^{-1}$ and can be calculated by Eq. 2 (Badawy et al., 2015; Ramola et al., 2011):

$$
\mathrm{Ra}_{\mathrm{eq}}\left(\mathrm{Bq} \cdot \mathrm{kg}^{-1}\right)=\mathrm{A}_{\mathrm{Ra}}+1.43 \mathrm{~A}_{\mathrm{Th}}+0.077 \mathrm{~A}_{\mathrm{K}}
$$

The $A_{R a}, A_{T h}$ and $A_{K}$ are the radioactive effects of ${ }^{226} \mathrm{Ra}^{232} \mathrm{Th}$ and ${ }^{40} \mathrm{~K}$ in Bq.kg ${ }^{-1}$, respectively. The maximum allowable value of radium equivalent is $370 \mathrm{~Bq} \cdot \mathrm{kg}^{-1}$ (Tawfiq et al., 2015). Absorbed dose rate in air for gamma ray (D.) at $\mathrm{mL}$ above ground level can be calculated by using efficacy quality of ${ }^{226} \mathrm{Ra},{ }^{232} \mathrm{Th}$ and ${ }^{40} \mathrm{~K}$ as in Eq. 3 (Ramola et al., 2011):

$$
\operatorname{D\gamma }\left(\text { nGy.h }^{-1}\right)=0.462 \mathrm{~A}_{\mathrm{Ra}}+0.604 \mathrm{~A}_{\mathrm{Th}}+0.0417 \mathrm{~A}_{\mathrm{K}}
$$

$\mathrm{D} \cdot$ = The rate of Dose absorbed in $\mathrm{A}_{\mathrm{Ra}}, \mathrm{A}_{\text {th }}$

$A_{\mathrm{K}}=$ The efficacy quality of ${ }^{226} \mathrm{Ra},{ }^{232} \mathrm{Th}$ and ${ }^{40} \mathrm{~K} 40$ in Bq. $\mathrm{kg}^{-1}$

The Hazard guide $(\mathrm{H})$ is defined as a radiation factor used to determine external and internal radiation risks. The external risk index $\left(\mathrm{H}_{e x}\right)$ and the internal risk index $\left(\mathrm{H}_{\mathrm{in}}\right)$ are calculated by using Eq. 4 and 5 (Badawy et al., 2015; Tawfiq et al., 2015):

$$
\begin{aligned}
& \mathrm{H}_{\text {ex }}=\mathrm{A}_{\mathrm{Ra}} / 370+\mathrm{A}_{\mathrm{Th}} / 259+\mathrm{A}_{\mathrm{K}} / 4810 \\
& \mathrm{H}_{\text {in }}=\mathrm{A}_{\mathrm{Ra}} / 185+\mathrm{A}_{\text {Th }} / 259+\mathrm{A}_{\mathrm{K}} / 4810
\end{aligned}
$$

The $A_{R \curvearrowright}, A_{K}$ and $A_{T h}$ are the efficacy of radium-226 and thorium- 232 and potassium- 40 in Bq. $\mathrm{kg}^{-1}$. The external risk index $\left(\mathrm{H}_{\mathrm{ez}}\right)$ and internal risk index $\left(\mathrm{H}_{\mathrm{in}}\right)$ must also be $<1$. Annual Effective Dose Equivalent (AEDE) is defined as a radiation factor used to know the health effects of the absorbed dose and measured in mSv. $\mathrm{y}^{-1}$. The annual effective dose equivalent is estimated by using the conversion factor $0.7 \mathrm{~Sv}$. The $\mathrm{Gy}^{-1}$ which converts the absorbed dose in air to the effective dose as well as using indoor occupancy factor 0.8 and outdoor occupancy factor 0.2 as in Eq. 6 and 7 (Tawfiq et al., 2015; Mehra et al., 2009):

$$
\begin{aligned}
\operatorname{AEDE}_{\text {in }}\left(\mathrm{mSv}^{-1}\right)= & \mathrm{D}\left(\mathrm{nGy}^{-1}\right) \times 10^{-6} \times 8760 \mathrm{~h}^{-1} \times \\
& 0.7 \mathrm{~Sv} \cdot \mathrm{Gy}^{-1} \times 0.8 \\
\mathrm{AEDE}_{\text {out }}\left(\mathrm{mSv} \cdot \mathrm{y}^{-1}\right)= & \mathrm{D}\left(\mathrm{nGy} \cdot \mathrm{h}^{-1}\right) \times 10^{-6} \times 8760 \frac{\mathrm{h}}{\mathrm{y}} \times \\
& 0.7 \mathrm{~Sv} \cdot \mathrm{Gy}^{-1} \times 0.2
\end{aligned}
$$

Activity concentration index is an irradiation factor that estimate the risk levels of gamma-ray associated with natural radionuclides in samples and can be calculated by Eq. 8 (Hossain et al., 2010; Tawfiq et al., 2015):

$$
\mathrm{I}_{y}=\frac{\mathrm{A}_{\mathrm{Ra}}}{150}+\frac{\mathrm{A}_{\mathrm{Th}}}{100}+\frac{\mathrm{A}_{\mathrm{K}}}{1500}
$$


Table 1: Demonstrate the number, symbol and the name of area which the soil sample collect (Al-Hawija Technical Institute)

\begin{tabular}{ll}
\hline No and symbol of sample & Name of area \\
S1 & The new chancellery building \\
S2 & The site of chicken house inside the institute \\
S3 & The first campus \\
S4 & Department of Electrical Technique \\
S5 & The second campus \\
S6 & The workshop building \\
S7 & The sport building \\
S8 & The first student campus \\
S9 & The second student campus \\
\hline
\end{tabular}

Table 2: Specific activity concentration for all radionuclides in soil samples Specific activity concentrations (Bq. $\left.\mathrm{kg}^{-1}\right)$

\begin{tabular}{|c|c|c|c|c|c|c|}
\hline \multirow[b]{2}{*}{ No of samples } & \multicolumn{2}{|c|}{${ }^{238} \mathrm{U}\left(\mathrm{Bq} \cdot \mathrm{kg}^{-1}\right)$} & \multicolumn{2}{|c|}{${ }^{232} \mathrm{Th}\left(\mathrm{Bq} \cdot \mathrm{kg}^{-1}\right)$} & \multirow[b]{2}{*}{${ }^{137} \mathrm{Cs}\left(\mathrm{Bq} \cdot \mathrm{kg}^{-1}\right)$} & \multirow[b]{2}{*}{${ }^{40} \mathrm{~K}\left(\mathrm{~Bq} \cdot \mathrm{kg}^{-1}\right)$} \\
\hline & ${ }^{226} \mathrm{Ra}$ & ${ }^{214} \mathrm{~Pb}$ & ${ }^{212} \mathrm{~Pb}$ & ${ }^{228} \mathrm{Ac}$ & & \\
\hline S1 & $23.6 \pm 4.4$ & $11.6 \pm 0.6$ & $11 \pm 0.6$ & $13.6 \pm 0.8$ & $1.4 \pm 0.1$ & $232 \pm 6.6$ \\
\hline $\mathrm{S} 2$ & $21.3 \pm 4.9$ & $15 \pm 1.1$ & $16.6 \pm 1.1$ & $16 \pm 1.2$ & $0.6 \pm 0.2$ & $292 \pm 9.1$ \\
\hline S3 & $31.6 \pm 4.4$ & $14.1 \pm 1.1$ & $16.1 \pm 0.9$ & $14.6 \pm 0.9$ & $0.6 \pm 0.1$ & $284.4 \pm 6.1$ \\
\hline S4 & $28.4 \pm 4.8$ & $16.5 \pm 1.2$ & $17.2 \pm 4.3$ & $18.47 \pm 1.2$ & $0.8 \pm 0.2$ & $313.6 \pm 9.5$ \\
\hline S5 & $23.6 \pm 6.1$ & $11.4 \pm 0.7$ & $14.4 \pm 0.6$ & $12.4 \pm 0.8$ & $0.8 \pm 0.2$ & $242 \pm 6.4$ \\
\hline S6 & $32 \pm 6.1$ & $10.8 \pm 0.9$ & $10.6 \pm 0.7$ & $10.4 \pm 0.6$ & B.D.L & $221 \pm 7.5$ \\
\hline S7 & $25 \pm 3.9$ & $13.4 \pm 0.7$ & $12.2 \pm 0.6$ & $11.8 \pm 0.9$ & $2.6 \pm 0.2$ & $244.6 \pm 6.4$ \\
\hline S8 & $21 \pm 3.7$ & $11.6 \pm 0.6$ & $12.2 \pm 0.6$ & $13.6 \pm 0.8$ & $2.4 \pm 0.1$ & $265 \pm 6.9$ \\
\hline S9 & $38.2 \pm 6.7$ & $15.6 \pm 1.2$ & $16.2 \pm 0.9$ & $16.4 \pm 1.2$ & $0.8 \pm 0.2$ & $252 \pm 9.1$ \\
\hline Max & $38.2 \pm 6.7$ & $16.5 \pm 1.2$ & $17.2 \pm 4.3$ & $18.47 \pm 1.2$ & $2.6 \pm 0.2$ & $313.6 \pm 9.5$ \\
\hline Min & $21 \pm 3.7$ & $10.8 \pm 0.9$ & $10.6 \pm 0.7$ & $10.4 \pm 0.6$ & $\mathrm{BDL}$ & $221 \pm 7.5$ \\
\hline Ave & $27.19 \pm 4.9$ & $13.33 \pm 0.9$ & $14.05 \pm 1.4$ & $14.141 \pm 0.93$ & $1.25 \pm 0.14$ & $260.73 \pm 7.5$ \\
\hline $\begin{array}{l}\text { Global limit } \\
\text { (UNSCEAR., 2000a, b; } \\
\text { Cottens, 1990) }\end{array}$ & 35 & & 30 & & 14.8 & 420 \\
\hline
\end{tabular}

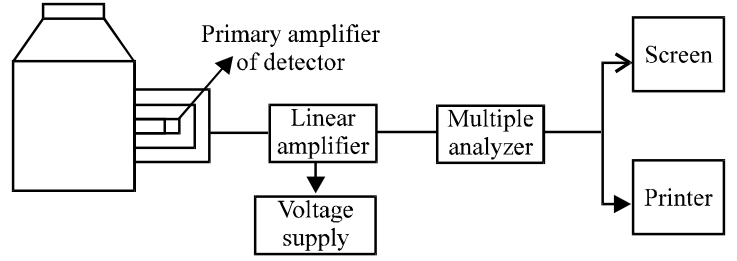

Fig. 1: Diagram for radioactive measurement system

Increasing the time or number of exposing to the radiation lead to increase the chance of happing the cancer for a specific level. This represented in the number of cancer cases happened for number of people when they expose to material for a specific level. Also ELCR can be determined form Eq. 9 if supposed the human old around 70 years (Taskin et al., 2009):

$$
\mathrm{ELCR}=\mathrm{AEDE} \times \mathrm{DL} \times \mathrm{RF}
$$

Since, $\mathrm{AEDE}$ is the annual equivalent active sample which determined from Eq. 10:

$$
\mathrm{AEDE}=\mathrm{AD} \times 1.23 \times 10^{-3}
$$

DL is average old of human (approximately 70 years old). RF is the dangers factor (UNSCEAR., 1993) which calculated by $\mathrm{Sv}^{-1}$ and probability dangers of happing of died cancer for each unit $\left(\mathrm{Sv}^{-1}\right)$. The back ground radiation with a low level will be generate a random effects. Since, the International Committee (ICRP 60) depends the value of 0.05 as a safe value for the general people Eq. 11:

$$
\begin{aligned}
\mathrm{EAD}= & \left(0.92 \mathrm{~A}_{\mathrm{U}}+1.1 \mathrm{~A}_{\mathrm{Th}}+0.08 \mathrm{~A}_{\mathrm{K}}\right) \times 10^{-9} \mathrm{~Gy} \cdot \mathrm{h}^{-1} \times \\
& 0.7 \mathrm{~Sv} . \mathrm{Gy}^{-1} \times 8760 \mathrm{~h} \cdot \mathrm{y}^{-1} \times 0.8
\end{aligned}
$$

Sample preparation: It has been collected nine samples of soil from nine different sites at Al-Hawija Technical Institute which all were under the occupation of ISIS and after that exposed to military operations with different types of weapons. Each sample dried then sifted, grinded well and became powder in average $0.5 \mathrm{~kg}$ Table 1 . Sample analyzed by a high purity germanium detector (Canberra Model) in Ministry of Environment (radiation protection center) (Fig. 1, Table 2), this detector is semiconductors (p-type) which needs to reduce the temperature to $-196^{\circ} \mathrm{C}$ by nitrogen liquid. The operating voltage is applied as a high approximately $4000 \mathrm{~V}$. The 


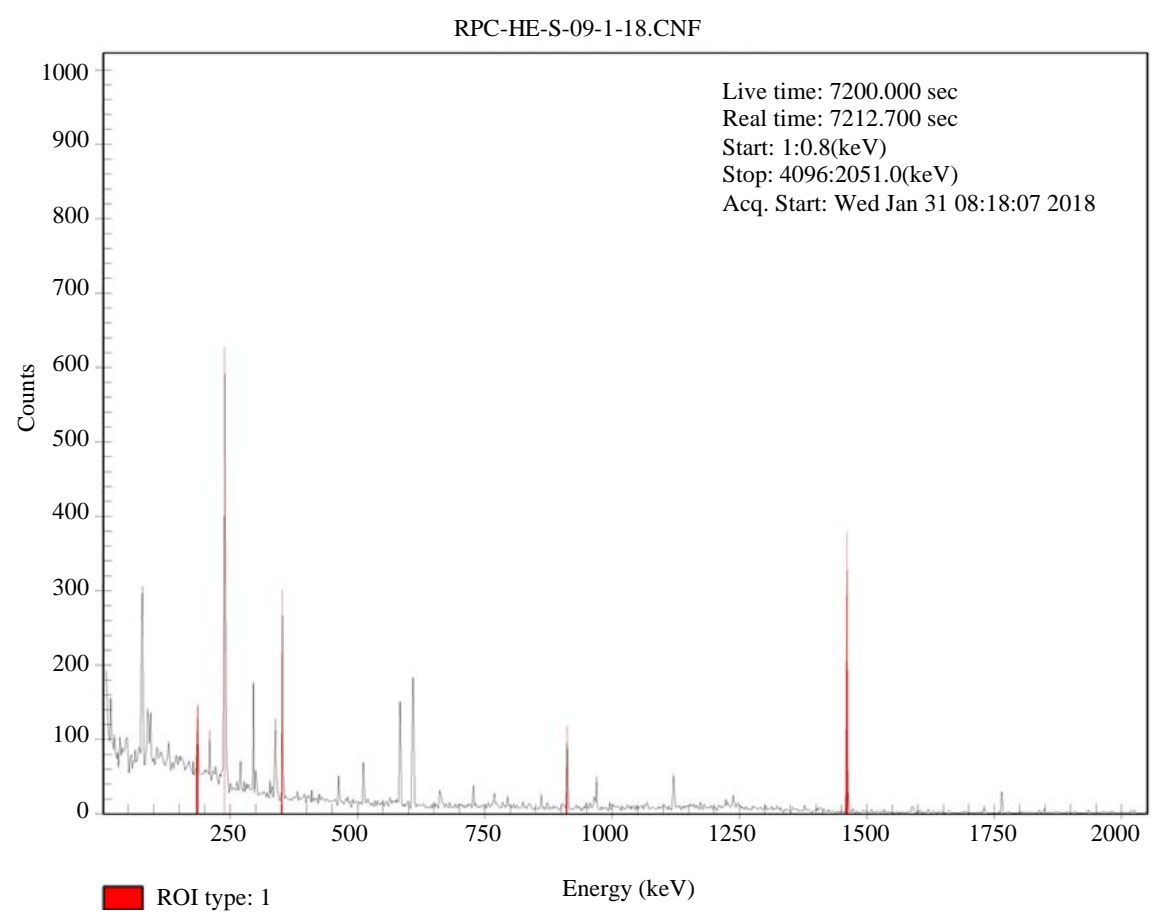

Fig. 2: The gamma radiation spectrum for soil Sample (S9)

detector was shield with lead of thickness of $10 \mathrm{~cm}$ and internally lined with cadmium and copper to reduce the $\mathrm{X}$-ray radiation that resulted from interaction between gamma ray and lead (IAEA., 2000). The gamma radiation spectrum soil Sample (S9) explained in Fig. 2.

\section{RESULTS AND DISCUSSION}

The specific activity concentration: In Table 2 the specific activity concentration for soil samples data are summarized, the result showed highest value of specific activity for Radium ${ }^{226} \mathrm{Ra} 38.2 \pm 6.7 \mathrm{Bg} \cdot \mathrm{kg}^{-1}$ in Sample (S9), this value is higher than the average international value for radium (35) Bg. $\mathrm{kg}^{-1}$ and the lowest value showed in (S8) sample $21 \pm 3.7 \mathrm{Bg} . \mathrm{kg}^{-1}$. The general average was 27.19 $\pm 4.9 \mathrm{Bg} . \mathrm{kg}^{-1}$ (Fig. 2) (UNSCEAR., 2000a, b; Cottens, 1990).

The lowest value of specific activity for ${ }^{214} \mathrm{~Pb}$ in Sample (S6) was $10.8 \pm 0.9 \mathrm{Bg} \cdot \mathrm{kg}^{-1}$ while the lowest value in Sample (S4) was $16.5 \pm 1.2 \mathrm{Bg} . \mathrm{kg}^{-1}$ and the average value $13.33 \pm 0.9$, this value in each sample is lower than the average international value for radium $35 \mathrm{Bg} \cdot \mathrm{kg}^{-1}$ (UNSCEAR., 2000a, b; Cottens, 1990).

In Fig. 3 it can be seen that the higher and lower specific activity concentration value for Thorium series ${ }^{232} \mathrm{Th}$ in $\mathrm{Bg} . \mathrm{kg}^{-1}$ unite for $\left({ }^{212} \mathrm{~Pb},{ }^{228} \mathrm{Ac}\right)$ in range 17.2 4 4.3$18.47 \pm 1.2$ in Sample S4 and 10.6 $\pm 0.7-10.4 \pm 0.6$ in Sample S6, respectively and the average value for Thorium

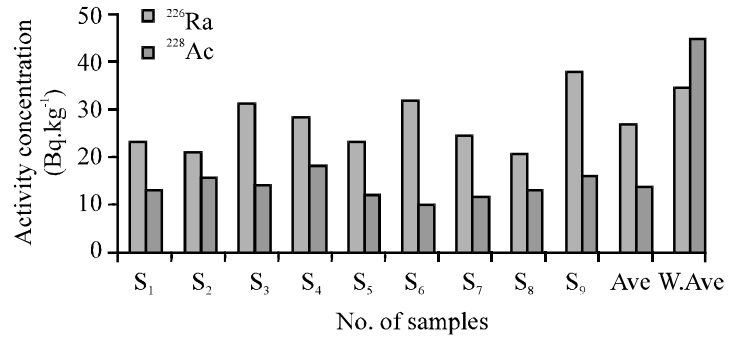

Fig. 3: Specific activity concentration for $\left({ }^{266} \mathrm{Ra}-{ }^{228} \mathrm{Ac}\right)$

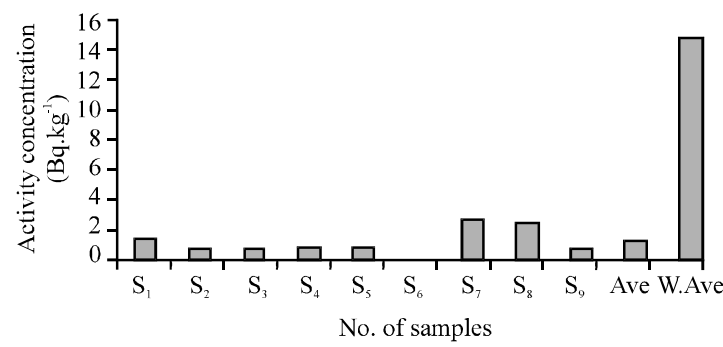

Fig. 4: Specific activity concentration for $\left({ }^{137} \mathrm{Cs}\right)$

series ${ }^{232} \mathrm{Th}$ was $14.05 \pm 1.4-14.141 \pm 0.93$, respectively, these results were lower than the average international value 30 Bg. $\mathrm{kg}^{-1}$ (IAEA., 2000; UNSCEAR., 2000a, b). The specific activity concentration value for Cesium ${ }^{137} \mathrm{Cs}$ in soil samples were lower than the average international value 14.8 Bg. $\mathrm{kg}^{-1}$ (UNSCEAR., 2000a, b; Cottens, 1990), 


\begin{tabular}{|c|c|c|c|c|c|c|c|c|c|}
\hline \multirow[b]{2}{*}{ No. of samples } & \multirow[b]{2}{*}{$\mathrm{Ra}_{\mathrm{eq}}\left(\mathrm{Bq} \cdot \mathrm{kg}^{-1}\right)$} & \multirow[b]{2}{*}{$\mathrm{I}_{\mathrm{a}}$} & \multicolumn{2}{|c|}{ Hazard index } & \multicolumn{2}{|c|}{ Annual effective dose $\left(\mathrm{mSv} \cdot \mathrm{y}^{1}\right)$} & \multirow{2}{*}{$\begin{array}{l}\text { Absorbed } \\
\text { dose rate } \\
\left(n G y \cdot h^{-1}\right) \\
\end{array}$} & \multirow{2}{*}{$\begin{array}{l}\text { ELCD } \\
* 10^{3}\end{array}$} & \multirow{2}{*}{$\begin{array}{l}\text { EAD } \\
\left(\mathrm{mSv} \cdot \mathrm{y}^{-1}\right)\end{array}$} \\
\hline & & & $\mathrm{H}_{\mathrm{ex}}$ & $\mathrm{H}_{\text {in }}$ & $\mathrm{AEDE}_{\text {in }}$ & $\mathrm{AEDE}_{\text {out }}$ & & & \\
\hline S1 & 60.912 & 0.448 & 0.165 & 0.228 & 0.142 & 0.036 & 29.023 & 0.125 & 0.271 \\
\hline $\mathrm{S} 2$ & 66.664 & 0.497 & 0.180 & 0.238 & 0.157 & 0.039 & 31.953 & 0.138 & 0.297 \\
\hline S3 & 74.377 & 0.546 & 0.201 & 0.286 & 0.174 & 0.044 & 35.525 & 0.153 & 0.333 \\
\hline S4 & 78.959 & 0.583 & 0.213 & 0.290 & 0.185 & 0.046 & 37.668 & 0.162 & 0.351 \\
\hline S5 & 59.966 & 0.443 & 0.162 & 0.226 & 0.141 & 0.035 & 28.695 & 0.124 & 0.268 \\
\hline S6 & 63.889 & 0.465 & 0.173 & 0.259 & 0.149 & 0.037 & 30.458 & 0.131 & 0.287 \\
\hline S7 & 60.708 & 0.448 & 0.164 & 0.232 & 0.143 & 0.036 & 29.078 & 0.125 & 0.272 \\
\hline S8 & 60.853 & 0.453 & 0.164 & 0.221 & 0.143 & 0.036 & 29.198 & 0.126 & 0.272 \\
\hline S9 & 81.056 & 0.587 & 0.219 & 0.322 & 0.188 & 0.047 & 38.341 & 0.165 & 0.360 \\
\hline Max & 81.056 & 0.587 & 0.219 & 0.322 & 0.188 & 0.047 & 38.341 & 0.165 & 0.360 \\
\hline Min & 59.966 & 0.443 & 0.162 & 0.221 & 0.141 & 0.035 & 28.695 & 0.124 & 0.268 \\
\hline Ave & 67.487 & 0.496 & 0.182 & 0.256 & 0.158 & 0.040 & 32.215 & 0.139 & 0.301 \\
\hline $\begin{array}{l}\text { Global limit } \\
\text { (UNSCEAR., 2000a, b; } \\
\text { Cottens, 1990) }\end{array}$ & 370 & 0.8 & 1 & 1 & 0.450 & 0.070 & 55 & 0.2900 & 1.5 \\
\hline
\end{tabular}

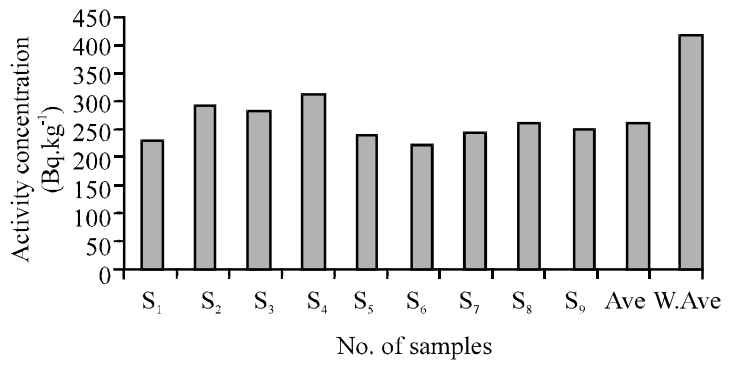

Fig. 5: Specific activity concentration for ${ }^{40} \mathrm{~K}$

the result showed lowest value in Sample (S6) was lower than detection value (B.D.L) and highest value was in Sample (S7) 2.6 $40.2 \mathrm{Bg} . \mathrm{kg}^{-1}$ with average value $1.25 \pm 0.14$ Bg.kg-1 (Fig. 4).

In Fig. 5 the specific activity concentration average value for potassium ${ }^{40} \mathrm{~K}$ was lower than the average international value $420 \mathrm{Bg} \cdot \mathrm{kg}^{-1}$ (Fig. 5), (UNSCEAR, 2000a, b; Cottens, 1990). The values were in range $221 \pm 7.53-313.6 \pm 9.5 \mathrm{Bg} . \mathrm{kg}^{-1}$ for (S4, S6), respectively.

Evaluation of radiological hazard effects for soil samples: The result showed that the average radium equivalent activity was $67.487 \mathrm{~Bq} \cdot \mathrm{kg}^{-1}$ and lower than the average international value of the radium equivalent activity recommended 370 Bq. $\mathrm{kg}^{-1}$ by using Eq. 2 this clearly appear in Table 3 (UNSCEAR., 2000a, b; Cottens, 1990). The average value for hazard Index gamma ray (I.) 0.496 was lower than the average international value $(0.8)$ by using Eq. 8 (UNSCEAR., 2000a, b; Cottens, 1990). It can be seen that the average value for external and internal hazard index in soil samples were lower than the average international value (1) Bg. $\mathrm{Kg}^{-1}$ bu using Eq. 4 and 5), respectively, Table 3 (UNSCEAR., 2000a, b; Cottens, 1990).
The internal annual effective dose equivalent values: The internal annual effective dose equivalent values was (0.141-0.188) for (S5-S9), respectively, in average value $(0.158)$, so, this value is lower than average international value (0.45) Table 3 (UNSCEAR., 2000a, b; Cottens, 1990). The result showed that the external annual effective dose equivalent average value $0.040 \mathrm{mSv} \cdot \mathrm{y}^{-1}$ was lower than average international value (0.07) Table $3, \mathrm{mSv} . \mathrm{y}^{-1}$. The average absorbed dose rate value in air for soil samples was $32.215 \mathrm{nGy} \cdot \mathrm{h}^{-1}$ this average value was lower than average international value (55) nGy.h ${ }^{-1}$ Table 3 (UNSCEAR., 2000a, b; Cottens, 1990). The average value of increased incidence of lung cancer (0.139) in soil samples was lower than average international value $(0.29)$ Table 3 (IAEA., 2000; UNSCEAR., 2000a, b). The external annual effective dose in all soil samples will be calculated, the average value was $\left(0.301 \mathrm{mSv} \cdot \mathrm{y}^{-1}\right)$ which is lower than average international value $1.5 \mathrm{mSv} \cdot \mathrm{y}^{-1}$, Table 3 (UNSCEAR., 2000a, b; Cottens, 1990).

\section{CONCLUSION}

In this study, the activity of the radiation has been measured both of the natural and industrial radiation in a different samples collected from the site of Al-Hawija Technical Institute. This study has been investigated by using HPGe detector have been obtained different points of conclusion.

The specific activity concentration values for $\left({ }^{40} \mathrm{~K}\right.$, ${ }^{137} \mathrm{Cs},{ }^{228} \mathrm{Ac},{ }^{212} \mathrm{~Pb},{ }^{214} \mathrm{~Pb},{ }^{226} \mathrm{Ra}$ ) in all the soil samples from Al-Hawija Technical Institute-Kirkuk Governorate were lower than the average international value. The average effects of the dangerous values which represented by the activity of the equivalent Radium $\left(\mathrm{Ra}_{\mathrm{eq}}\right)\left(67.487 \mathrm{~Bq} \cdot \mathrm{Kg}^{-1}\right)$. While the dangerous guide of gama ray (I.) (0.469). And The guide of the internal dangerous $\left(\mathrm{H}_{\mathrm{in}}\right)$ and external $\left(\mathrm{H}_{\mathrm{ez}}\right)(0.182),(0.256)$, respectively. Whenever, the annual 
active injection for the internal exposing $\left(\mathrm{AEDE}_{\text {out }}\right)(0.040)$ $\mathrm{mSv} \cdot \mathrm{y}^{-1}$ while the annual active injection for the outer exposing $\left(\mathrm{AEDE}_{\mathrm{in}}\right)\left(0.158 \mathrm{mSv} \cdot \mathrm{y}^{-1}\right)$ and the average injection absorbed by air (D.) (32.215 nGy. $\left.\mathrm{n}^{-1}\right)$. Also, increasing the time of exposing for radiation leads to happening the cancer (ELCR) (0.139). Since, the annual external active injection (EAD) $\left(0.301 \mathrm{mSv} \cdot \mathrm{y}^{-1}\right)$. In the sample of the soil is lower than the international limits.

\section{REFERENCES}

Badawy, W.M., S.U. El-kameesy, N.F. Soliman, H.S. Eissa and A.W. Mahmoud, 2015. Natural radioactivity and the associated dose from the terrestrial ecosystem of Ismailia Canal, Egypt. Intl. J. Adv. Res., 3: 768-778.

Cottens, E., 1990. Actions against radon at the international level. Proceedings of the International Symposium on SRBI, January 17, 1990, Royal Society of Engineers and Industrial of Belgium, Brussels, Belgium, pp: 1-17.

Green, B.M.R., P.R. Lomas and M.C. O'Riordan, 1992. Radon in dwellings in England. Master Thesis, National Radiological Protection, Board, Chilton, UK.

Hossain, M.K., S.M. Hossain and A.M.H. Meaze, 2010. Assessment of radiological contamination of soils due to shipbreaking using HPGe digital gamma-ray spectrometry system. J. Environ. Prot., 1: 10-14.

IAEA., 2000. Generic procedures for monitoring in a nuclear or radiological emergency. International Atomic Energy Agency (IAEA), Vienna, Austria. https://www.iaea.org/ru/publications/6260/genericprocedures-for-monitoring-in-a-nuclear-or-radiologi cal-emergency-russian-version

Mehra, R., S. Singh and K. Singh, 2009. Analysis of $226 \mathrm{Ra}, 232 \mathrm{Th}$ and $40 \mathrm{~K}$ in soil samples for the assessment of the average effective dose. Indian J. Phys., 83: 1031-1037.
Ramola, R.C., V.M. Choubey, G. Prasad, G.S. Gusain and Z. Tosheva et al., 2011. Radionuclide analysis in the soil of Kumaun Himalaya, India, using gamma ray spectrometry. Curr. Sci., 100: 906-914.

Selvaskarapadian, S., R. Silvakumar and N.M. Manikandan, 2000. Natural radionuclide distribution in soils of Gudalore, India. Applied Radia Isot., 52: 299-306.

Taskin, H., M. Karavus, P. Ay, A. Topuzoglu and S. Hidiroglu et al., 2009. Radionuclide concentrations in soil and lifetime cancer risk due to gamma radioactivity in Kirklareli, Turkey. J. Environ. Radioact., 100: 49-53.

Tawfiq, N.F., H.L. Mansour and M.S. Karim, 2015. Natural radioactivity in soil samples for selected regions in Baghdad governorate. Int. J. Recent Res. Rev., 8: $1-7$.

UNEP., 2000. Depleted uranium in Kosovo, post-conflict environment assessment. United Nations Environment Programme, ?Nairobi?, Kenya. https://www. unenvironment.org/resources/report/d epleted-uranium-kosovo-post-conflict-environment al-assessment

UNSCEAR, 2000a. Sources and Effects of Ionizing Radiation. United Nations Scientific Committee on the Effect of Atomic Radiation United Nations, New York.

UNSCEAR., 1988. Sources, Effects and Risks of Ionizing Radiation. United Nation Scientific Committee on the Effects of Atomic Radiation, New York, USA., ISBN:92-1-1421 43-8, Pages: 647.

UNSCEAR., 1993. United nations scientific committee on the effects of atomic radiation. Ionizing Radiation: Sources and Effects of Ionizing Radiation, New York, USA.

UNSCEAR., 2000b. Sources and Effects of Ionizing Radiation: Sources. United Nations Publications, New York, USA., ISBN:92-1-142238-8, Pages: 657. 